\title{
Serum Testosterone and Cognitive Function in Ageing Male: Updating the
} Evidence

\section{Vito A. Giagulli, Edoardo Guastamacchia, Brunella Licchelli and Vincenzo Triggiani}

\author{
Interdisciplinary Department of Medicine-Section of Internal Medicine, Geriatrics, Endocrinology and \\ Rare Diseases. University of Bari "A. Moro", Bari, Italy
}

Received: April 22, 2016; Revised: May 20, 2016; Accepted: May 24, 2016

\begin{abstract}
Background: Testosterone (T) deficit, either in prepubertal or postpubertal form of hypogonadism, seems to play a key role in impairing cognitive function, including memory, attention, language and visuospatial abilities, especially in elderly men.
\end{abstract}

Objective: Several studies have recently showed the association between low serum T levels and important cognitive dysfunctions in ageing male as well as in subjects suffering from Alzheimer's disease (AD), mild cognitive impairment (MCI) and even depression, suggesting that $\mathrm{T}$ could exert an active neuroprotective role.

\begin{abstract}
Methods: By searching PubMed and recent patents (ranging from 2010 to 2015), we identified several observational and intervention studies dealing with $\mathrm{T}$ and cognitive function in adult and ageing men. Findings were reviewed, thoroughly examined and, finally, summarized herein.
\end{abstract}

Results: Although a large number of studies have been carried out so far, conclusive evidence cannot be drawn, in particular, for cognitive disorders in males. Conversely, $\mathrm{T}$ supplementation has been suggested for depressive syndrome in young and ageing men. To date, no clinical data have been carried out on cognitive dysfunctions employing the quoted patents in men.

Conclusions: Studies aiming to evaluate the role of serum $\mathrm{T}$ and its supplementation in adult and ageing men with $\mathrm{T}$ deficiency syndrome need to be encouraged, given that subjects affected by overt hypogonadism, either in prepubertal (i.e. Klinefelter syndrome) or postpubertal forms (chemical castration in subjects affected by prostate cancer), often complain of cognitive dysfunction, and seem to considerably benefit from $T$ replacement therapy.

Keywords: Ageing male, Alzheimer's disease, cognitive dysfunction, depression, male hypogonadism, testosterone deficiency Syndrome.

\section{INTRODUCTION}

Cognitive performance, consisting in attention, memory, language and visuospatial abilities, declines as men grow older [1-3]. Given that in western countries elderly people are expected to be increasing in number in the next few years, the number of men affected by mild cognitive impairment (MCI) [4], dementia and Alzheimer's disease (AD) [5] is estimated to be rising too. In this context, it is not surprising that the cost of those patients' care is estimated over $\$$ 180 billion per year in the United States [6].

Although the prevalence of cognitive dysfunctions may be different depending on the definition and methodology employed, it proves to be higher in adult-old men than in young ones. Indeed, moderate forms of memory impairment occur in about $13 \%$ of adults aged more than 65 , while it can be diagnosed in more than $30 \%$ in men over 80 . On the other

*Address correspondence to this author at the Interdisciplinary Department of Medicine Section of Internal Medicine, Geriatrics, Endocrinology and Rare Diseases. University of Bari "A. Moro" Piazza Giulio Cesare, 70123 Bari, Italy; Tel:/Fax: 00390804091368; E-mail vitogiagulli@alice.it hand, if memory impairment is defined according to the National Institute of Mental Health criteria, its prevalence turns out to be about $40 \%$ in individuals aged $60-80$ [7]. However, $25 \%$ of men aged $68-78$ have been found to suffer from "aging-associated cognitive decline" as defined by the International Psychogeriatric Association [8]. Finally, the prevalence of mild cognitive impairment (MCI) that is a transitional state between the normal ageing process and overt Alzheimer's disease (AD), can be estimated between 3 and $30 \%$ in men aged more than 75 [9].

It is generally accepted that several hormones may have an important role in brain organization and development and in sexual orientation during fetal life or in behavior, neuroprotection and cognitive functions in adult and aging subjects. A lot of research about the role of hormones in cognition has been undertaken, as well as several intervention studies have been carried out to evaluate the effect of the substitutive hormone therapy on those patients affected by cognitive loss. As a matter of fact, thyroid [10] glucocorticoid [11] and mineralcorticoid hormones [12] prove to affect brain functions in young and elderly men. However, in men 
sexual hormones and especially $\mathrm{T}$ seem to have a key role in modulating some brain functions such as those involved in sexual orientation, depression and cognitive abilities (especially learning, memory and spatial cognitions) [13].

The male ageing process is characterized by a gradual decline of testosterone ( $\mathrm{T}$ ) levels, as well as by a significant rise in serum levels of Sex hormone Binding Globulin (SHBG) [14] which, notwithstanding $\mathrm{T}$ metabolic clearance has been shown to be reduced in ageing men [15], brings about a steeper decrease in circulating free T (FT) than serum $T$ [16]. This natural event may be worsened in the presence of diseases and comorbid conditions (i.e. obesity, metabolic diseases, renal failure, diabetes mellitus, etc.) and even medications that can often be prescribed for those diseases causing the exacerbation of the same ageing process. In addition, the serum $\mathrm{T}$ reduction can contribute to alterations in body composition (i.e. obesity) [17], diminution in energy, muscle strength, sexual activity, depressed mood, cognitive functions and might even affect heart function [18-20]. As a result, one in ten over the age of 50, and one in five over the age of 60 may be found to have hypogonadal levels of serum $\mathrm{T}(<300 \mathrm{mg} / \mathrm{dl})[14,21]$. Nowadays overt hypogonadal men can, however, be treated by means of different $\mathrm{T}$ preparations [22] or rather, when associated with those clinical conditions (obesity, metabolic syndrome, type 2 diabetes mellitus, etc) often underpinning or causing $\mathrm{T}$ reduction in adult and elderly men, lifestyle changes and drugs targeting obesity and diabetes mellitus should be even taken into consideration [23].

In male, hypogonadism is considered an important factor in the derangement of cognitive function and physical performance $[24,25]$, given that $\mathrm{T}$ is considered as having a neuroprotective role [26-28]. Cognitive impairment, in fact, could be an important element of the clinical picture in subjects suffering from androgen-insensitivity syndrome [29] as well as both in young subject affected by primary (Klinefelter Syndrome) and secondary hypogonadism $[30,31]$ and in patients affected by late-onset hypogonadism (LOH). Moreover, in adult-elderly men a decrease of serum $\mathrm{T}$ levels $[32,33]$ and an increase of serum SHBG levels [34, 35] are associated with a higher risk of AD. This being the case, hormone therapy, particularly Testosterone replacement therapy (TRT) has been suggested to prevent or improve cognitive dysfunction or to prevent the onset of dementia in men with TDS.

This review aims to analyze and sum up the current clinical evidence about the possible relationship between serum $\mathrm{T}$ reduction and cognitive function in older men.

\section{METHODS}

An accurate research was made in PubMed and Embase databases using the following criteria: observational studies, clinical trials, randomized controlled trials, review papers and meta-analysis published in English in peer-reviewed journals after 1990. Keywords used were: male hypogonadism, late-onset hypogonadism, testosterone therapy, cognitive dysfunctions, and ageing male. All those papers which did not meet the above-mentioned initial search criteria were excluded. Finally, patents pertinent to $\mathrm{T}$ and its related compounds were examined. As a matter of fact, we conducted a detailed search on line of the most relevant recent (20102015) patents (in particular in www.google.com/paptens, www.uspto.gov, http://espacenet.com, www.freepaptensonline.com, www.wipo.int/pctdb/en/search-simp.jsp, www. freshpaptents.com and www.scopus.com) in order to identify more suitable ones for $\mathrm{T}$ substitution in patients suffering both from cognitive disorders and $\mathrm{T}$ deficit.

\section{MAJOR EFFECTS OF T IN THE ADULT BRAIN}

So far, the organizational effect as well as the neurotrophic and neuroprotective mechanisms of $\mathrm{T}$ on the adult brain has not been wholly understood yet. Current evidence has been obtained either from in vitro research or from preclinical observational studies.

As in other target tissues, $\mathrm{T}$ can be metabolized in dihydrotestosterone (DHT) (by means of the $5 \alpha$ reductase enzyme) or converted into $17 \beta$ estradiol (by means of the aromatase enzyme) in the brain. As a result, $\mathrm{T}$ and DHT bind androgen receptor (AR), while 17ßestradiol (E2) binds estrogen receptor (ER). Ultimately, AR intracellular signalling can modify gene expressions such as CREB activation [36]. Both aromatase and $5 \alpha$ reductase enzymes as well as AR and ER are found in the key regions of the brain involved in spatial learning and memory such as in the hippocampus and in the amygdale $[37,38]$. Furthermore, a smaller hippocampus volume has been found in those subjects with lower free $\mathrm{T}$ and at least a copy of Apolipoproteine E polymophisme4 which is considered as a risk factor for AD (Table 1) [39].

Table 1. Major Proposed Effects of $T$ and its Active Metabolite in the Brain.

Nurotrophic role of T

1. Nuclear effects modifying gene expression (i.e. CREB activation)

2. Cell differentiation and neurite growth

3. Development of motor and autonomic neurons

4. Regulation of glial activity

Nuroprotective role of $\mathrm{T}$

1. Stress antioxidant effects

2. Anti-apoptotic effects of neuronal cells

3. Up-regulating nerve growth factor (NGF)

4. Stimulating basal respiration and mitochondrial membrane potential

In addition, ARs are exclusively found in asymmetric synapses [40], while ERs are localized in both asymmetric and symmetric synapses [41].

Testosterone has been found to have neuroprotective effects against oxidative stress [42] and cell apoptosis [43]. Furthermore, the neuroprotective effect of $\mathrm{T}$ may be mediated by the positive effect of $\mathrm{T}$ in increasing the concentration of the nerve growth factor (NGF) in the hippocampus and in up-regulating its receptor in the forebrain [44]. 
Different in vitro studies (Table 1) carried out either in animals or in humans, have demonstrated an active neuroprotective role of $\mathrm{T}$ in the processes involved in $\mathrm{AD}$. As a matter of fact, in male double-transgenic mice the increase of $\mathrm{T}$ corresponds to a decrease in $\beta$-secretase, an enzyme responsible for the cleavage of the amyloid $\beta$ protein precursor $[13,45]$. In culture of hyppocampal neurons, $T$ may reduce $\beta$-amyloid induced neurotoxicity [46], while preserving the integrity of neurites, reducing the expression of oligomeric $\beta$-amyloid peptide on presynaptic terminals. Moreover, these effects seem to be independent of estrogens and their receptor, as that positive effect did not change when letrozole (an aromatase inhibitor) was added [47]. Finally, $\mathrm{T}$ was more effective in alleviating $\beta$-amyloid induced mitochondrial bioenergetic deficits in cultures of human neuroblastoma cells [48]. Recently, in a human SH-SY5Y neuroblastoma culture study, T increased ATP level, basal respiration and mitochondrial membrane potential [49]. It has been proposed, therefore, that $\mathrm{T}$ may regulate energy production by inducing nuclear and mitochondrial oxidative phosphorylation (OXPHOS) genes, given that subunit mitochondrial chain complexes are encoded by nuclear and the mitochondrial genome, respectively, and both contain hormone responsive elements [50].

In hypogonadal men, preclinical studies conducted by using imaging techniques have shown some interesting data about the different brain region activations before or after a short time (3-4 weeks) of replacement therapy. For instance, Zitzmann et al. [51], studying the cerebral glucose metabolism by $18 \mathrm{~F}$ deoxyglucose positron emission tomography during standardized mental rotation task in 6 hypogonadal men before and after TRT, showed that $\mathrm{T}$ substitution improved visuospatial performance with cerebral glucose metabolism enhancement during the test. In hypogndal men, using single photon emission computed tomography, TRT was able to increase the cerebral perfusion in the midbrain and the superior frontal gyrus, while the midcingulate gyrus turned out to be active after 3 months of TRT [52]. Furthermore, in female-to male transexualism $\mathrm{T}$ therapy has an enhancing effect on spatial ability performance, while an opposite effect is described in male-to female transexualism receiving an androgen deprivation therapy [53].

Finally, androgen deprivation therapy (ADT) (whether it is chemical or surgical) which is routinely used in the treatment of prostate cancer, may be regarded as an interesting model to study the effect of $T$ withdrawal on cognitive function in men. In an observational study of over 40 men with prostate cancer who were treated with chemical ADT for 36 months, the impairment of cognitive functions was correlated with the rise in serum $\beta$-amyloid levels, while the discontinuation of that treatment improved their cognitive functions [54]. Another study carried out in 26 older men suffering from prostate cancer provided a selective decline in cognitive performance over 6 and 12 months with ADT, with visuomotor skills slowing down, reduced reaction time and working memory [55]. Nineteen men with prostate cancer who underwent chemical ADT, showed a worsened spatial rotation score, but an improved score for verbal memory during that therapy [56]. Lastly, two recent studies have found that men receiving ADT because of prostate cancer, experienced more symptoms of fatigue than those related to an impairment of cognitive performance $[57,58]$. In conclusion, this preliminary evidence suggests that treatments reducing serum $\mathrm{T}$ levels in men with prostate cancer may impair performance in some cognitive domains especially in spatial ability. Further studies are needed, however, to determine the suitability of ADT as a model for determining hormonal effects on cognitive functions given the time spans of those studies and, in particular, the frequent presence of important comorbidities (i.e. metabolic diseases, hypertension and osteoporosis, etc.) in these patients $[59,60]$.

\section{COGNITIVE FUNCTIONS AND TDS STUDIES}

Although several studies have been conducted about the relationship between TDS and cognitive functions in men suffering from hypogonadism, many questions remain unsolved. Indeed, the appropriate study population has not been established yet, while the interventional studies have not shown wholly consistent results, being the randomized controlled trials (RCT) still limited.

In the next pages, however, we have summarized the principal observational and interventional studies about $\mathrm{T}$ and cognitive-related outcomes in hypogonadal men [60].

\section{Observational Studies}

Almost all of the cross-sectional studies carried out in different western countries consisting of a large number of participants with middle-old age (50-80 years), have supported the relationship between low circulating $(\mathrm{F}) \mathrm{T}$ levels and poor cognitive performance [32, 35, 61-64]. Moreover, some of them $[35,61]$ also showed that E2 levels were inversely correlated with cognitive functions in hypogonadal men. Only two surveys $[65,66]$ found no association between $\mathrm{T}$ (and its free fraction) and various cognitive measurements. Although those researches have been well conducted and the data adjusted for age, education and in some studies co-variants such as alcohol consumption, body mass index (BMI) and depression were taken into account in the statistical analysis, all of the studies had a potential limitation which consisted in the fact that the method employed to measure serum $\mathrm{T}$ and $\mathrm{E} 2$ was the immunoassays instead of the mass spectrometry and no studies were carried out measuring serum FT [32] by dialitic method which is commonly considered the gold standard [67].

Given that cross-sectional studies cannot examine the outcome of dementia and although some longitudinal studies were carried out on a large number of men with the average age of 50-80, they were not able to infer the direction of causality, as all cross-sectional studies do. In particular, in 2 studies the examined population observed for 10 and 19 years, respectively, showed the association of high T/SHBG ratio with low risk to develop Alzheimer's dementia $[1,68]$. Conversely, other 2 longitudinal analysis of a large number of men aged 71-93, one from the Honolulu-Asian Aging Study followed for a mean of over 6 years and the second one from the Osteoporosis Fractures Study [69], did not present that association, rather showing that higher bio-available E2 levels predict increased incidence of AD [70].Therefore, these latest studies added further complexity to the relationship between sex hormone levels and cognitive function impairment in men. However, even though the published data 
have limitations, on balance those studies suggested the association between low serum $\mathrm{T}$ levels and, to a limited extent, low E2 levels with impairment of cognitive function in middle-aged and old men [60].

\section{Intervention Studies of Testosterone Treatment on Cog- nitive Functions}

Several randomized placebo-controlled trials (RCTs) aiming to verify the positive effects on cognitive function in men have been carried out so far (Table 2). However, the results may be regarded as being inconclusive because of the following reasons: limited number of participants, different $\mathrm{T}$ formulation used, duration of treatment, range of cognitive tests and outcomes [71].

Most of the RCTs lasted up to 12 weeks, yielded a significant enhancement of spatial cognition in middle-aged and old males, while other cognitive functions such as verbal memory, dexterity and cognitive flexibility were not positively affected $[72,73]$. Conversely, in three studies of which 2 were of the duration of 1 year, no effect of $\mathrm{T}$ therapy on cognitive functions was observed [74-76]. However, besides those inconclusive and still open results obtained in middleaged and old men, it is remarkable the fact that $T$ replacement therapy improved the cognitive impairment caused by suppression of endogenous $\mathrm{T}$ productions by means of Levonorgestrel (LN) [77] or GnRH agonist [78] in young men (21-45 years old).

Interestingly, two principal metabolites of $\mathrm{T}$ (E2 and DHT) may have some effects on specific areas of cognitive performance. Indeed, E2 and DHT might improve cognitive functions in terms of verbal memory or attention, respectively. Cherrier et al. [79] showed that in a 6 weeks study in which subjects were given intramuscularly $\mathrm{T}(100 \mathrm{mg} /$ week $)$ with and without an aromatase inhibitor (anastazole orally $1 \mathrm{mg}$ /day), only those men receiving $\mathrm{T}$ alone enhanced verbal memory. Another study by Cherrier et al. [80] compared a group of old men with hypogonadism on $\mathrm{T}$ gel therapy with another group on DHT gel. In this research, there wasn't a placebo group. $\mathrm{T}$ treated men showed an improvement of verbal memory, whilst those treated with DHT enhanced spatial memory. Finally, Vaughan et al. [81] conducted a study in which 60-86 year-old men showed low-normal levels of $\mathrm{T}(<350 \mathrm{mg} / \mathrm{dl})$ and were treated with $\mathrm{T}(100 \mathrm{mg}$ intramuscularly/2 weeks) with or without oral Finasteride ( $5 \mathrm{mg} /$ day) which inhibits the conversion of T into DHT. Although several cognitive functions did not show treatmentrelated differences, attention was enhanced in those subjects treated only with $\mathrm{T}$, while verbal functions improved in those who were given $\mathrm{T}$ and Finasteride. However, it is worth underlining that additional studies are needed to verify and clarify the possible benefits of rising serum E2 and/or DHT levels in order to improve different cognitive activities in men [60].

Some studies, however, highlighted the role the serum $\mathrm{T}$ levels might have reached during the therapy in comparison with the obtained effects on the cognitive function in men. Different researches [82, 83], in fact, some of the RCTs [78, 84], have borne out the importance of T levels achieved during TRT in the study in relation to cognitive functions. As a matter of fact, if the effects of TRT on body composition and, in particular, the enhancement of muscle mass could be obtained by means of normal $\mathrm{T}$ levels, the effects on different cognitive outcomes can be obtained reaching higher serum $\mathrm{T}$ levels, for instance giving an injection of 100 or 300 $\mathrm{mg}$ of $\mathrm{T}$ [78, 80, 83-85]. This evidence, in fact, bears out those data that, in the elderly men, psychosomatic complaints and metabolic risk are related to testosterone levels in a symptom-specific manner [86]. The work of Gray et al. can be considered on same wavelength [87]. They examined the effects of graded testosterone doses on sexual function, mood, and visuospatial cognition in healthy, older men (age, $60-75 y r)$ who were given a long-acting $\mathrm{GnRH}$ agonist to suppress endogenous testosterone production and were randomized to receive one of five doses $(25,50,125,300$, and $600 \mathrm{mg}$ ) of testosterone enanthate weekly for $20 \mathrm{wk}$. Although, no effects of testosterone dose were observed on two measures of mood (Hamilton's Depression Inventory and Young's Mania Scale), the authors found differences in visuospatial cognition across treatment groups, with highest scores in men on highest dose $(600 \mathrm{mg} / \mathrm{week})$. Conversely, Maki et al. [88] gave testosterone enanthate $(200 \mathrm{mg}$ i.m. every other week for 90d) crossed over with placebo to 50 cognitively normal eugonadal men, aged 66-86yr. Performance was assessed on a standardized verbal memory test, and brain activity (relative glucose metabolic rates) in medial temporal and frontal regions was measured with positron emission tomography during a verbal memory task. A1though that treatment was able to increase serum T by $241 \%$, the behavioral results showed a significant decrease in shortdelay verbal memory with treatment and a non-significant decrease on a composite verbal memory measure. On the other hand, Positron emission tomography scans revealed a relative decreased activity in ventromedial temporal cortex (i.e. right amygdala/entorhinal cortex) and a relative increased activity in bilateral prefrontal cortex with treatment. In conclusion, decreased verbal memory and altered relative activity in medial temporal and prefrontal regions suggest possible detrimental effects of supraphysiological testosterone supplementation in elderly men.

\section{Intervention Studies of Testosterone Treatment on De- mentia}

So far, relatively few randomized placebo controlled studies aiming at improving the cognitive functions have been carried out about TRT in men suffering from dementia (Table 2). Those studies made up of populations of some old men ( $>70$ years old) affected by $\operatorname{AD}[27,89,90]$, while others with MCI [27, 91], lasting between 6 to 52 weeks, showed, beside the improvement of quality of life, a significant enhancement of visual-spatial ability, spatial memory and verbal memory. However, the possible role of aromatization of $\mathrm{T}$ into $\mathrm{E} 2$ on cognitive outcomes in patients with $\mathrm{AD}$ and MCI needs further experiences [91].

\section{REVIEWING RECENT PATENTS}

An extensive evaluation of the most recent patents (ranging from 2010 to 2015) was carried out in order to verify the most appropriate ones for the treatment of patients with $\mathrm{T}$ deficit and cognitive disorders. Taking into consideration the 
Table 2. Testosterone Treatment and Cognitive Functions: Intervention Studies.

\begin{tabular}{|c|c|c|c|c|c|}
\hline Study/Author/Year & $\begin{array}{l}\text { Age (Yrs) } \\
\text { (m/ Range) }\end{array}$ & $\begin{array}{l}\text { Duration } \\
\text { (Weeks) }\end{array}$ & Dose & Results & Ref. \\
\hline $\begin{array}{c}\text { Cherrier } 2005 \\
\text { (CI or AD) }\end{array}$ & $63-85$ & 6 & T 100mg im weekly & $\begin{array}{c}\text { Improved spatial memory and ability, and verbal } \\
\text { memory; No differences in verbal fluency or } \\
\text { attention }\end{array}$ & {$[27]$} \\
\hline Janowsky 1994 & 67.4 & 12 & $\begin{array}{l}\mathrm{T} \text { (scrotal patch) } \\
15 \mathrm{mg} / \text { daily }\end{array}$ & $\begin{array}{l}\text { Improved spatial cognition. No effect on verbal } \\
\text { memory, dexterity and cognitive flexibility }\end{array}$ & {$[72]$} \\
\hline Cherrier 2001 & $50-80$ & 6 & $\mathrm{~T}$ (im) $100 \mathrm{mg} /$ weekly & $\begin{array}{l}\text { Improved spatial memory and ability, and verbal } \\
\text { memory; No effect on attention or verbal fluency }\end{array}$ & {$[73]$} \\
\hline Sih 1997 & $51-79$ & 52 & $\mathrm{~T}$ (im) $200 \mathrm{mg} / 2$ weekly & No effect on memory, recall or verbal fluency & {$[74]$} \\
\hline Kenny 2002 & 76.4 & 52 & $\mathrm{~T} 2.5 \mathrm{mg}$ patch daily & $\begin{array}{l}\text { No difference in cognitive test results between } \\
\text { groups }\end{array}$ & {$[75]$} \\
\hline Kenny 2004 & 80 & 12 & T 200mg im 3 weekly & $\begin{array}{l}\text { No difference in cognitive test results between } \\
\text { groups }\end{array}$ & {$[76]$} \\
\hline Cherrier 2002 & $21-46$ & 8 & $\begin{array}{l}\text { T (im) } 100 \mathrm{mg} / \text { weekly }+ \\
\text { LN } 125 \mathrm{mcg} \text { oral/day }\end{array}$ & $\begin{array}{l}\text { Decreased performance in tests of verbal memory in } \\
\text { LN-treated group, improved selective attention in T } \\
+ \text { LN group }\end{array}$ & {$[77]$} \\
\hline Young 2010 & $\begin{array}{l}25-35 \\
60-80\end{array}$ & 6 & $\begin{array}{l}\text { GnRH suppression, T gel } \\
100 \text { or } 75 \mathrm{mg} \mathrm{im} \pm \text { AN } 1 \\
\text { mg/day oral }\end{array}$ & $\begin{array}{l}\text { On-treatment free } \mathrm{T} \text { or free E2 positively associated } \\
\text { with spatial cognition; On-treatment free E2 nega- } \\
\text { tively associated with working memory }\end{array}$ & [78] \\
\hline Cherrier 2005 & $50-90$ & 6 & $\begin{array}{c}\mathrm{T} 100 \mathrm{mg} \text { im weekly } \pm \mathrm{AN} \\
1 \mathrm{mg} \text { oral/day }\end{array}$ & $\begin{array}{c}\text { Improved spatial memory in } \mathrm{T} \text { and } \mathrm{T}+\mathrm{AN} \text { groups, } \\
\text { improved verbal memory in } \mathrm{T} \text { group only }\end{array}$ & [79] \\
\hline Vaughan 2007 & $65-83$ & 156 & $\begin{array}{l}\text { T 200mg im } 2 \text { weekly } \pm \text { F } \\
5 \mathrm{mg} \text { oral/day }\end{array}$ & $\begin{array}{c}\text { No differences in multiple cognitive tests; except for } \\
\text { improved verbal memory with } \mathrm{T}+\mathrm{F} \text {, improved } \\
\text { attention with } \mathrm{T} \text { only }\end{array}$ & {$[81]$} \\
\hline Haren 2005 & $60-86$ & 52 & T 80mg oral (twice daily) & $\begin{array}{l}\text { No difference in visuomotor tracking and visuospa- } \\
\text { tial ability }\end{array}$ & {$[82]$} \\
\hline Emmelot-Yonk 2008 & $60-80$ & 26 & T 80mg oral (twice daily) & $\begin{array}{l}\text { No differences in verbal memory, perceptual speed, } \\
\text { attention, or visuospatial performance }\end{array}$ & [83] \\
\hline Cherrier 2007 & $50-90$ & 6 & $\begin{array}{l}\text { T } 50,100 \text { or } 200 \mathrm{mg} \text { im } \\
\text { weekly }\end{array}$ & $\begin{array}{c}\text { Improved verbal and spatial memory associated with } \\
\text { moderate increases in } \mathrm{T} \text {, not with low or large in- } \\
\text { creases }\end{array}$ & {$[84]$} \\
\hline Gray 2005 & $60-75$ & 20 & $\begin{array}{l}\text { GnRH suppression }+\mathrm{T} \\
25,50,125,300,600 \mathrm{mg} \\
\text { im weekly }\end{array}$ & $\begin{array}{c}\text { Differences in visuospatial cognition across treat- } \\
\text { ment groups, with highest scores in men on highest } \\
\text { dose (600mg/week) }\end{array}$ & {$[87]$} \\
\hline Maki 2007 & $66-86$ & 13 & T 200mg im 2 weekly & $\begin{array}{l}\text { No difference in working memory and attention, } \\
\text { decreased recall }\end{array}$ & {$[88]$} \\
\hline $\begin{array}{l}\text { Tan } 2003 \\
(\mathrm{CI} \text { or } \mathrm{AD})\end{array}$ & $68-80$ & 52 & T 200mg im 2 weekly & Improved general cognition and visuospatial ability & [89] \\
\hline $\begin{array}{l}\text { Lu } 2006 \\
\text { (CI or AD) }\end{array}$ & $\begin{array}{l}69.8 \\
62.3\end{array}$ & 24 & T gel $75 \mathrm{mg}$ daily & $\begin{array}{l}\text { Trend to improvement in visuospatial function in } \\
\text { AD men, no difference in verbal memory }\end{array}$ & {$[90]$} \\
\hline $\begin{array}{l}\text { Sherwin } 2011 \\
\text { (CI or AD) }\end{array}$ & 75.9 & 12 & E2 1mg oral daily & $\begin{array}{l}\text { Improvement in verbal memory; No differences in } \\
\text { global cognitive function or visuospatial ability }\end{array}$ & [91] \\
\hline
\end{tabular}

Legends: T: Testosterone, LN: Levonorgestrel, AN: Astanazole, F: Finasteride, E2: Estradiol, AD: Alzheimers' Disease, CI: Cognitive Impairment 
goals for accurate TRT in adult men with T deficiency and suffering from cognitive dysfunction as well as the therapeutic appropriateness and the potential adverse effects of TRT in adult and/or elderly men [22], we considered some of them as being unsuitable. In particular, the association of $T$ with selective serotonin reuptake inhibitors such as buspirone drug [92] which is given for male sexual dysfunction, while pharmaceutical agent that can enhance serum $\mathrm{T}$ or encapsulated cells (ovary cells) for $\mathrm{T}$ treatment should be regarded as inappropriate treatment either for the difficulty to obtain adequate range of $\mathrm{T}$ levels or for the technical difficulties $[93,94]$. In addition, the compound consisting in $\mathrm{T}$ plus anastrozole should be not considered as an appropriate $\mathrm{T}$ substitution, given that the aromatase inhibitor role of anastrozole might cause a reduction of bone mass density in hypogonadal patients who generally could suffer from osteoporosis [95] while the ones administerd nasally (spray and gel) were less easy to use, often causing nasal discomfort, nasopharyngitis, bronchitis, upper respiratory tract infection, sinusitis, and nasal scab [96, 97].

Those patents which propone $\mathrm{T}$ therapy given transcutaneously or perorally can be adequate formulations for TRT [98-106], although it is worthy reporting that oral $\mathrm{T}$ compounds ( $\mathrm{T}$ undecanoate) can raise serum DHT levels which is not advisable in elderly men [107], while percutaneous ones have a large within-individual variations in serum $\mathrm{T}$, showing, therefore, a higher variability of its plasma levels [108]. It is interesting the patent which, using transdermal preparations (sprays, lotions, pastes, creams, etc) of clomiphene-like selective estrogen receptor modulator (SERM), can increase serum T levels in hypogonadal men [109]. As a matter of fact, this compound given orally can increase serum $\mathrm{T}$ levels both in obese hypogonadal men and in those with infertility, avoiding the possible side effects that TRT might determine in adult and elderly men $[110,111]$. Finally, a recent patent characterized by a compound that stimulates the production of $\mathrm{T}$ through transmucosal administration is proposed as a treatment aiming at preventing the onset of Alzheimer's diseases. This product is a truffle extract that provides an olfactory stimulus by smelling $T$ that is, naturally, contained in any type of truffle [112]. However, to date, there has been no clinical evidence about patents compound in hypogonadal old men affected by cognitive dysfunction.

\section{CURRENT \& FUTURE DEVELOPMENTS}

Although a considerable amount of in vitro and in vivo evidence points out the relationship between $\mathrm{T}$ declining (as does aging male) and cognitive dysfunctions, they are not considered as specific signs or symptoms for the overt hypogonadism in young and adult men [113]. Indeed, TRT has not been envisaged for the cognitive disorders in the International guidelines for the diagnosis and treatment of male hypogonadism [113], while $\mathrm{T}$ substitution has been suggested for hypogonadal men suffering from depression [114]. Indeed, these inconclusive results could stem from the fact that the data that have been provided so far, were collected in population made up of small number of participants, often observed for a short period of time and by a determination of $\mathrm{T}$ by means of those methods which should not be considered as being accurate. In addition, there have been limited RCT results of TRT in elderly men with MCI and or dementia where the risks versus the benefit of hormonal substitution have been carefully considered [114]. However, it is worth of note underlining that young and adult patients with overt hypogonadism often complain of cognitive dysfunctions which can be overcome by means of TRT [60]. In conclusion, it is desirable that further randomized controlled studies should be conducted even by means of accurate methods for the measurement of serum $\mathrm{T}$ and its free fraction.

\section{CONFLICT OF INTEREST}

The authors confirm that this article content has no conflict of interest.

\section{ACKNOWLEDGEMENTS}

All Authors were involved in the initial conception, design, drafting and final approval of the complete study. In particular, V.A. Giagulli contributed substantially to acquisition, analysis and revising of data for intellectual content.

This work was supported by philanthropic and personal sources of funding.

\section{REFERENCES}

[1] Moffat SD, Zonderman AB, Metter EJ, Blackman MR, Harman SM, Resnick SM. Longitudinal assessment of serum free testosterone concentration predicts memory performance and cognitive status in elderly men. J Clin Endocrinol Metab 2002; 87(11): 50017 .

[2] Lehert P, Villaseca P, Hogervost E, Mak PM, Henderson VW. Individually modifiable risk factors to ameliorate cognitive aging: A systematic review and meta-analysis. Climacteric 2015; 18(5): 678-89.

[3] Hsu B, Cumming RG, Waite LM, Blyth FM, Naganathan V, Le Couteur DG, et al. Longitudinal relationships between reproductive hormones and cognitive decline in older men: The concord health and ageing in men project. J Clin Endocrinol Metab 2015; 100(6): 2223-30.

[4] Guathier S, Reisberg B, Zaudig M, Petersen RC, Ritchie K, Broich $\mathrm{K}$, et al. Mild cognitive impairment. Lancet 2006; 367(9518): 1262-70.

[5] Stern Y. Cognitive reserve in ageing and Alzheimer's disease. Lancet Neurol 2012; 11(11): 1006-12.

[6] Stefanacci RG. The costs of Alzheimer's disease and the value of effective therapies. Am J Manag Care 2011; 17 (Suppl 13): S35662.

[7] Koivisto K, Reinikainen KJ, Hänninen T, Vanhanen M, Helkala EL, Mykkänen L, et al. Prevalence of age-associated memory impairment in a randomly selected population from eastern Finland. Neurology 1995; 45(4): 741-7.

[8] Hanninen T, Koivisto K, Reinikainen KJ, Helkala EL, Soininen H, Mykkänen L, et al. Prevalence of ageing-associated cognitive decline in an elderly population. Age Ageing 1996; 25(3): 201-5.

[9] Busse A, Bischkopf J, Riedel-Heller SG, Angermeyer MC. Mild cognitive impairment: Prevalence and incidence according to different diagnostic criteria. Results of the leipzig longitudinal study of the aged (LEILA75+). Br J Psychiatry 2003; 182: 449-54.

[10] Resta F, Triggiani V, Barile G, Benigno M, Suppressa P, Giagulli VA, et al. Subclinical hypothyroidism and cognitive dysfunction in the elderly. Endocr Metab Immune Disord Drug Targets 2012; 12(3): $260-7$

[11] Notarianni E. Hypercortisolemia and glucocorticoid receptorsignaling insufficiency in Alzheimer's disease initiation and development. Curr Alzheimer Res 2013; 10(7): 714-31.

[12] MacKenzie SM, Dewar D, Stewart W, Fraser R, Connell JM, Davies $\mathrm{E}$. The transcription of steroidogenic genes in the human cere- 
bellum and hippocampus: A comparative survey of normal and Alzheimer's tissue. J Endocrinol 2008; 196(1): 123-30.

[13] Blair JA, McGee H, Bhatta S, Palm R, Casadesus G. Hypothalamic-pituitary-gonadal axis involvement in learning and memory and Alzheimer's disease: More than "just" estrogen. Front Endocrinol 2015; 6: 45 .

[14] Harman SM, Metter EJ, Tobin JD, Pearson J, Blackman MR. Baltimore longitudinal study of aging. Longitudinal effects of aging on serum total and free testosterone levels in healthy men. Baltimore longitudinal study of aging. J Clin Endocrinol Metab 2001; 86(2): 724-31.

[15] Coviello AD, Lakshman K, Mazer NA, Bhasin S. Differences in the apparent metabolic clearance rate of testosterone in young and older men with gonadotropin suppression receiving graded doses of testosterone. J Clin Endocrinol Metab 2006; 91(11): 4669-75.

[16] Kaufman JM, Vermeulen A. The decline of androgen levels in elderly men and its clinical and therapeutic implications. Endocr Rev 2005; 26(6): 833-76.

[17] Giagulli VA, Kaufman JM, Vermeulen A. Pathogenesis of the decreased androgen levels in obese men. J Clin Endocrinol Metab 1994; 79(4): 997-1000.

[18] Matsumoto AM. Andropause: Clinical implications of the decline in serum testosterone levels with aging in men. J Gerontol A Biol Sci Med Sci 2002; 57(2): M76-99.

[19] Giagulli VA, Moghetti P, Kaufman JM, Guastamacchia E, Iacoviello M, Triggiani V. Managing erectile dysfunction in heart failure. Endocr Metab Immune Disord Drug Targets 2013; 13(1): $125-34$.

[20] Giagulli V.A, Guastamacchia E, De Pergola G, Iacoviello M, Triggiani $\mathrm{V}$. Testosterone deficiency in male: A risk factor for heart failure. Endocr Metab Immune Disord Drug Targets 2013; 13(1): 92-9.

[21] Mulligan T, Frick MF, Zuraw QC, Stemhagen A, McWhirter C. Prevalence of hypogonadism in males aged at least 45 years: The HIM study. Int J Clin Pract 2006; 60(7): 762-9.

[22] Giagulli V.A, Triggiani V, Corona G, Carbone D, Licchelli B, Tafaro E, et al. Evidence-based medicine update on testosterone replacement therapy (TRT) in male hypogonadism: Focus on new formulations. Curr Pharm Des 2011; 17(15): 1500-11.

[23] Giagulli V.A, Carbone MD, Ramunni MI, Licchelli B, De Pergola $\mathrm{G}$, Sabbà $\mathrm{C}$, et al. Adding liraglutide to lifestyle changes, metformin and testosterone therapy boosts erectile function in diabetic obese men with overt hypogonadism. Andrology 2015; 3(6): 1094103.

[24] Krasnoff JB, Basaria S, Pencina MJ, Jasuja GK, Vasan RS, Ulloor $\mathrm{J}$, et al. Free testosterone levels are associated with mobility limitation and physical performance in community-dwelling men: The Framingham Offspring Study. J Clin Endocrinol Metab 2010; 95(6): 2790-9.

[25] Hyde Z, Flicker L, Almeida OP, Hankey GJ, McCaul KA, Chubb $\mathrm{SA}$, et al. Low free testosterone predicts frailty in older men: The health in men study. J Clin Endocrinol Metab 2010; 95(7): 316572 .

[26] Okun MS, Fernandez HH, Rodriguez RL, Romrell J, Suelter M, Munson S, et al. Testosterone therapy in men with Parkinson disease: Results of the TEST-PD Study. Arch Neurol 2006; 63(5): 729-35.

[27] Cherrier MM, Matsumoto AM, Amory JK, Asthana S, Bremner W, Peskind ER, et al. Testosterone improves spatial memory in men with Alzheimer disease and mild cognitive impairment. Neurology 2005; 64(12): 2063-8.

[28] Cherrier MM. Testosterone effects on cognition in health and disease. Front Horm Res 2009; 37: 150-62.

[29] Imperato-McGinley J, Pichardo M, Gautier T, Voyer D, Bryden MP. Cognitive abilities in androgen-insensitive subjects: Comparison with control males and females from the same kindred. Clin Endocrinol (Oxf) 1991; 34(5): 341-7.

[30] Boada R, Janusz J, Hutaff-Lee C, Tartaglia N. The cognitive phenotype in Klinefelter syndrome: A review of the literature including genetic and hormonal factors. Dev Disabil Res Rev 2009; 15(4): 284-94.

[31] Lašaitė L, Ceponis J, Preikša RT, Zilaitienė B. Impaired emotional state, quality of life and cognitive functions in young hypogonadal men. Andrologia 2014; 46(10): 1107-12.
[32] Hogervorst E, Bandelow S, Combrinck M, Smith AD. Low free testosterone is an independent risk factor for Alzheimer's disease. Exp Gerontol 2004; 39(11-12): 1633-9.

[33] Butchart J, Birch B, Bassily R, Wolfe L, Holmes C. Male sex hormones and systemic inflammation in Alzheimer disease. Alzheimer Dis Assoc Disord 2012; 27(2): 153-6.

[34] Muller M, Schupf N, Manly JJ, Mayeux R, Luchsinger JA. Sex hormone binding globulin and incident Alzheimer's disease in elderly men and women. Neurobiol Aging 2010; 31(10): 1758-65.

[35] Yaffe K, Lui LY, Zmuda J, Cauley J. Sex hormones and cognitive function in older men. J Am Geriatr Soc 2002; 50(4): 707-12.

[36] Nguyen TV, Yao M, Pike CJ. Dihydrotestosterone activates CREB signaling in cultured hippocampal neurons. Brain Res 2009; 1298 $1-12$

[37] Tohgi H, Utsugisawa K, Yamagata M, Yoshimura M. Effects of age on messenger RNA expression of glucocorticoid, thyroid hormone, androgen, and estrogen receptors in postmortem human hippocampus. Brain Res 1995; 700(1-2): 245-53.

[38] Sarkey S, Azcoitia I, Garcia-Segura LM, Garcia-Ovejero D, DonCarlos LL. Classical androgen receptors in non-classical sites in the brain. Horm Behav 2008; 53(5): 753-64.

[39] Panizzon MS, Hauger R, Xian H, Vuoksimaa E, Spoon KM, Mendoza SP, et al. Interaction of APOE genotype and testosterone on episodic memory in middle-aged men. Neurobiol Aging 2014; 35(7): 1778.e1-8.

[40] Tabori NE, Stewart LS, Znamensky V, Romeo RD, Alves SE, McEwen BS, et al. Ultrastructural evidence that androgen receptors are located at extranuclear sites in the rat hippocampal formation. Neuroscience 2005; 130(1): 151-63.

[41] Milner TA, McEwen BS, Hayashi S, Li CJ, Reagan LP, Alves SE. Ultrastructural evidence that hippocampal alpha estrogen receptors are located at extranuclear sites. J Comp Neurol 2001; 429(3): 35571.

[42] Cunningham RL, Singh M, O'Bryant SE, Hall JR, Barber RC. Oxidative stress, testosterone, and cognition among Caucasian and Mexican-American men with and without Alzheimer's disease. J Alzheimers Dis 2014; 40(3): 563-73.

[43] Hammond J, Le Q, Goodyer C, Gelfand M, Trifiro M, LeBlanc A. Testosterone-mediated neuroprotection through the androgen receptor in human primary neurons. J Neurochem 2001; 77(5): 131926.

[44] Tirassa P, Thiblin I, Agren G, Vigneti E, Aloe L, Stenfors C. Highdose anabolic androgenic steroids modulate concentrations of nerve growth factor and expression of its low affinity receptor (p75NGFr) in male rat brain. J Neurosci Res 1997; 47(2): 198-207.

[45] McAllister C, Long J, Bowers A, Walker A, Cao P, Honda S, et al. Genetic targeting aromatase in male amyloid precursor protein transgenic mice down-regulates beta-secretase (BACE1) and prevents Alzheimer-like pathology and cognitive impairment. J Neurosci $2010 ; 30(21): 7326-34$

[46] Pike CJ. Testosterone attenuates beta-amyloid toxicity in cultured hippocampal neurons. Brain Res 2001; 919(1): 160-5.

[47] Lau CF, Ho YS, Hung CH, Wuwongse S, Poon CH, Chiu K, et al. Protective effects of testosterone on presynaptic terminals against oligomeric $\beta$-amyloid peptide in primary culture of hippocampal neurons. Biomed Res Int 2014; 2014: 103906.

[48] Grimm A, Biliouris EE, Lang UE, Götz J, Mensah-Nyagan AG, Eckert A. Sex hormone-related neurosteroids differentially rescue bioenergetic deficits induced by amyloid- $\beta$ or hyperphosphorylated tau protein. Cell Mol Life Sci 2016; 73(1): 201-15.

[49] Grimm A, Schmitt K, Lang UE, Mensah-Nyagan AG, Eckert A. Improvement of neuronal bioenergetics by neurosteroids: Implications for age-related neurodegenerative disorders. Biochim Biophys Acta $2014 ; 1842(12 \mathrm{Pt} \mathrm{A}): 2427-38$

[50] Vasconsuelo A, Milanesi L, Boland R. Actions of 17ß-estradiol and testosterone in the mitochondria and their implications in aging. Ageing Res Rev 2013; 12(4): 907-17.

[51] Zitzmann M, Weckesser M, Schober O, Nieschlag E. Changes in cerebral glucose metabolism and visuospatial capability in hypogonadal males under testosterone substitution therapy. Exp Clin Endocrinol Diabetes 2001; 109(5): 302-4.

[52] Azad N, Pitale S, Barnes WE, Friedman N. Testosterone treatment enhances regional brain perfusion in hypogonadal men. J Clin Endocrinol Metab 2003; 88(7): 3064-8.

[53] Slabbekoorn D, van Goozen SH, Megens J, Gooren LJ, CohenKettenis PT. Activating effects of cross-sex hormones on cognitive 
functioning: A study of short-term and long-term hormone effects in transsexuals. Psychoneuroendocrinology 1999; 24(4): 423-47.

[54] Almeida OP, Waterreus A, Spry N, Flicker L, Martins RN. One year follow-up study of the association between chemical castration, sex hormones, beta-amyloid, memory and depression in men. Psychoneuroendocrinology 2004; 29(8): 1071-81.

[55] Salminen EK, Portin RI, Koskinen A, Helenius H, Nurmi M. Associations between serum testosterone fall and cognitive function in prostate cancer patients. Clin Cancer Res 2004; 10(22): 7575-82.

[56] Cherrier MM, Rose AL, Higano C. The effects of combined androgen blockade on cognitive function during the first cycle of intermittent androgen suppression in patients with prostate cancer. $\mathrm{J}$ Urol 2003; 170(5): 1808-11.

[57] Joly F, Alibhai SM, Galica J, Park A, Yi QL, Wagner L, et al. Impact of androgen deprivation therapy on physical and cognitive function, as well as quality of life of patients with nonmetastatic prostate cancer. J Urol 2006; 176(6 Pt 1): 2443-7.

[58] Alibhai SM, Breunis H, Timilshina N, Marzouk S, Stewart D, Tannock I, et al. Impact of androgen-deprivation therapy on cognitive function in men with nonmetastatic prostate cancer. J ClinOncol 2010; 28(34): 5030-7.

[59] Beauchet O. Testosterone and cognitive function: Current clinical evidence of a relationship. Eur J Endocrinol 2006; 155(6): 773-81.

[60] Yeap BB. Hormonal changes and their impact on cognition and mental health of ageing men. Maturitas 2014; 79(2): 227-35.

[61] Barrett-Connor E, Goodman-Gruen D, Patay B. Endogenous sex hormones and cognitive function in older men. J Clin Endocrinol Metab 1999; 84(10): 3681-5.

[62] Muller M, Aleman A, Grobbee DE, de Haan EH, van der Schouw YT. Endogenous sex hormone levels and cognitive function in aging men: Is there an optimal level? Neurology 2005; 64(5): 866-71.

[63] Thilers PP, Macdonald SW, Herlitz A. The association between endogenous free testosterone and cognitive performance: A population-based study in 35 to 90 year-old men and women. Psychoneuroendocrinology 2006; 31(5): 565-76.

[64] Yeap BB, Almeida OP, Hyde Z, Chubb SA, Hankey GJ, Jamrozik $\mathrm{K}$, et al. Higher serum free testosterone is associated with better cognitive function in older men, while total testosterone is not. The Health In Men Study. Clin Endocrinol (Oxf) 2008; 68(3): 404-12.

[65] Fonda SJ, Bertrand R, O'Donnell A, Longcope C, McKinlay JB. Age, hormones, and cognitive functioning among middle-aged and elderly men: Cross-sectional evidence from the Massachusetts male aging study. J Gerontol A BiolSci Med Sci 2005; 60(3): 385-90.

[66] Yonker JE, Eriksson E, Nilsson LG, Herlitz A. Negative association of testosterone on spatial visualization in 35 to 80 year old men. Cortex 2006; 42(3): 376-86.

[67] Vermeulen A, Verdonck L, Kaufman JM. A critical evaluation of simple methods for the estimation of free testosterone in serum. J Clin Endocrinol Metab 1999; 84(10): 3666-72.

[68] Moffat SD, Zonderman AB, Metter EJ, Kawas C, Blackman MR, Harman SM, et al. Free testosterone and risk for Alzheimer disease in older men. Neurology 2004; 62(2): 188-93.

[69] LeBlanc ES, Wang PY, Janowsky JS, Neiss MB, Fink HA, Yaffe $\mathrm{K}$, et al. Association between sex steroids and cognition in elderly men. Clin Endocrinol (Oxf) 2010; 72(3): 393-403.

[70] Geerlings MI, Strozyk D, Masaki K, Remaley AT, Petrovitch H, Ross GW, et al. Endogenous sex hormones, cognitive decline, and future dementia in old men. Ann Neurol 2006; 60(3): 346-55.

[71] Holland J, Bandelow S, Hogervorst E. Testosterone levels and cognition in elderly men: A review. Maturitas 2011; 69(4): 322-37.

[72] Janowsky JS, Oviatt SK, Orwoll ES. Testosterone influences spatial cognition in older men. Behav Neurosci 1994; 108(2): 325-32.

[73] Cherrier MM, Asthana S, Plymate S, Baker L, Matsumoto AM, Peskind E, et al. Testosterone supplementation improves spatial and verbal memory in healthy older men. Neurology 2001; 57(1): $80-8$.

[74] Sih R, Morley JE, Kaiser FE, Perry HM $3^{\text {rd }}$, Patrick P, Ross C. Testosterone replacement in older hypogonadal men: A 12-month randomized controlled trial. J Clin Endocrinol Metab 1997; 82(6):1661-7.

[75] Kenny AM, Bellantonio S, Gruman CA, Acosta RD, Prestwood KM. Effects of transdermal testosterone on cognitive function and health perception in older men with low bioavailable testosterone levels. J Gerontol A Biol Sci Med Sci 2002; 57(5): M321-5.

[76] Kenny AM, Fabregas G, Song C, Biskup B, Bellantonio S. Effects of testosterone on behavior, depression, and cognitive function in older men with mild cognitive loss. J Gerontol A BiolSci Med Sci 2004; 59(1): 75-8.

[77] Cherrier MM, Anawalt BD, Herbst KL, Amory JK, Craft S, Matsumoto AM, et al. Cognitive effects of short-term manipulation of serum sex steroids in healthy young men. J Clin Endocrinol Metab 2002; 87(7): 3090-6.

[78] Young LA, Neiss MB, Samuels MH, Roselli CE, Janowsky JS. Cognition is not modified by large but temporary changes in sex hormones in men. J Clin Endocrinol Metab 2010; 95(1): 280-8.

[79] Cherrier MM, Matsumoto AM, Amory JK, Ahmed S, Bremner W, Peskind ER, et al. The role of aromatization in testosterone supplementation: Effects on cognition in older men. Neurology 2005; 64(2): 290-6.

[80] Cherrier MM, Craft S, Matsumoto AH. Cognitive changes associated with supplementation of testosterone or dihydrotestosterone in mildly hypogonadal men: A preliminary report. J Androl 2003; 24(4): 568-76.

[81] Vaughan C, Goldstein FC, Tenover JL. Exogenous testosterone alone or with finasteride does not improve measurements of cognition in healthy older men with low serum testosterone. J Androl 2007; 28(6): 875-82.

[82] Haren MT, Wittert GA, Chapman IM, Coates P, Morley JE. Effect of oral testosterone undecanoate on visuospatial cognition, mood and quality of life in elderly men with low-normal gonadal status. Maturitas 2005; 50(2): 124-33.

[83] Emmelot-Vonk MH, Verhaar HJ, Nakhai Pour HR, Aleman A, Lock TM, Bosch JL, et al. Effect of testosterone supplementation on functional mobility, cognition, and other parameters in older men: A randomized controlled trial. JAMA 2008; 299(1): 39-52.

[84] Cherrier MM, Matsumoto AM, Amory JK, Johnson M, Craft S, Peskind ER, et al. Characterization of verbal and spatial memory changes from moderate to supraphysiological increases in serum testosterone in healthy older men. Psychoneuroendocrinology 2007; 32(1): 72-9.

[85] Birzniece V, Umpleby MA, Poljak A, Handelsman DJ, Ho KK. Oral low-dose testosterone administration induces whole-body protein anabolism in postmenopausal women: A novel liver-targeted therapy. Eur J Endocrinol 2013; 169(3): 321-7.

[86] Zitzmann M, Faber S, Nieschlag E. Association of specific symptoms and metabolic risks with serum testosterone in older men. J Clin Endocrinol Metab 2006; 91(11): 4335-43.

[87] Gray PB, Singh AB, Woodhouse LJ, Storer TW, Casaburi R, Dzekov J, et al. Dose-dependent effects of testosterone on sexual function, mood, and visuospatial cognition in older men. J Clin Endocrinol Metab 2005; 90(7): 3838-46.

[88] Maki PM, Ernst M, London ED, Mordecai KL, Perschler P, Durso $\mathrm{SC}$, et al. Intramuscular testosterone treatment in elderly men: Evidence of memory decline and altered brain function. J Clin Endocrinol Metab 2007; 92: 4107-14.

[89] Tan RS, Pu SJ. A pilot study on the effects of testosterone in hypogonadal aging male patients with Alzheimer's disease. Aging Male 2003; 6(1): 13-17.

[90] Lu PH, Masterman DA, Mulnard R, Cotman C, Miller B, Yaffe K, et al. Effects of testosterone on cognition and mood in male patients with mild Alzheimer disease and healthy elderly men. Arch Neurol 2006; 63(2): 177-85.

[91] Sherwin BB, Chertkow H, Schipper H, Nasreddine Z. A randomized controlled trial of estrogen treatment in men with mild cognitive impairment. Neurobiol Aging 2011; 32(10): 1808-17.

[92] Tuiten, J.J.A., Bloemers, J.M.M., De Large, R.P.J. Use of testosterone and 5-HT1A agonist in the treatment of sexual dysfunction. US921334 (2015).

[93] Opara, E.C. Encapsulated cells for treating low testosterone in male subjects. WO2015095028 (2015).

[94] Komai, M., Shirakawa, H., Ohsaki, Y., Ito, A., Sato, T., Ozaki, R. Agent for increasing testosterone level. EP2033634 (2009).

[95] Wang, T.C., Biundo, B.V. Testosterone combined with anastrozole injection solution. US20140371186 (2014).

[96] Merkus, F.W.H.M. Testosterone solution for the treatment of testosterone deficiency. EP2605778 (2015).

[97] Krepper, W., Maes, P.J.P.M. Male testosterone titration methods, male intranasal testosterone bio-adhesive gel formulation and use thereof for treating hypogonadism an TRT. WO2014080283 (2014).

[98] Ramana, M., Jodì, M. Improved testosterone gel and method of use. EP2450041 (2012). 
[99] Salin-Drounin, D. Testosterone gel comprising propylene glycol as penetration enhancer. EP2957279 (2015).

[100] Logomasini, M.A. Use of a novel subcutaneous needle-free technique to deliver testosterone in hypogonadal men. US20140171918 (2014).

[101] Nacheagari, S.K., Giliyar, C., Patel, R., Nachiappan, C., Venkateshwaran, S., Patel, M.V. Lipobalanced long chian testosterone prodrugs for oral delivery. US20140288039 (2014).

[102] Giliyar, C., Chickmath, B., Nachiappan, C., Patel, M., Venkateshwaran, S. High-strength testosterone undecanoate composition. US20160074416 (2016).

[103] Betageri, G.U., Thirucote, R., Kada, Kadajji, V.G. Proliposomal testosterone formulation. US20140112986 (2014).

[104] Grenier, A., Carrara, D.N. Testosterone formulations. US20130295166 (2013).

[105] Pimplasker, H.K. Testosterone gel compositions and related method. US20150164913 (2015).

[106] Chickmath, B., Giliar, C., Nachiappan, C., Patel, M.V., Venkateshwaran, S. Testosterone undecanoate compositions. US20150018324 (2015).

[107] Giagulli VA, Verdonck L, Deslypere JP, Giorgino R, Vermeulen A. Comparison of plasma androgen glucoronide levels after percutanneous or peroral androgen treatment in men: Evidence important splanchic contribution to plasma 17 beta-hydroxyandrogen glucoronide. J Clin Endocrinol Metab 1993; 76: 429-31.
[108] Swerdloff RS, Pak Y, Wang C, Liu PY, Bhasin S, Gill TM, et al. Serum testosterone $(\mathrm{T})$ level variability in $\mathrm{T}$ gel-trated older hypogonadal men: Treatment monitoring implications. J Clin Endocrinol Metab 2015; 100: 3280-7.

[109] Wang, T.C., Biundo, B.V. Transdermal pharmaceutical composition including C-SERMs for low testosterone levels in men. US20160051497 (2016).

[110] Bender SV, Murray P, Basaria S. Clomiphene citrate effectively increases testosterone in obese, young, hypogonadal men. Reprod Syst Sex Disord 2015; 4(4).

[111] Fernandez-Balsells MM, Murad MH, Lane M, Lampropulos JF, Albuquerque F, Mullan RJ, et al. Adverse effects of testosterone therapy in adult men: A systematic review and meta-analysis. J Clin Endocrinol Metab 2010; 95: 2560-75.

[112] Shifrine, M. Testosterone olfaction. US20130296140 (2013).

[113] Bhasin S, Cunningham GR, Hayes FJ, Matsumoto AM, Snyder PJ, Swerdloff RS, et al. Testosterone therapy in men with androgen deficiency syndromes: An Endocrine Society clinical practice guideline. J Clin Endocrinol Metab 2010; 95(6): 2536-59.

[114] Isidori AM, Balercia G, Calogero AE, Corona G, Ferlin A, Francavilla $\mathrm{S}$, et al. Outcomes of androgen replacement therapy in adult male hypogonadism: Recommendations from the Italian society of endocrinology. J Endocrinol Invest 2015; 38(1):1 03-12. 